\title{
Economics of Chilli Cultivation in Khammam District of Telangana
}

\author{
B. Raja Madhu Shaker*, J. Hemantha Kumar, V. Chaitanya, \\ P. Sriranjitha, K. Ravi Kumar and P. Jagan Mohan Rao \\ Krishi Vigyan Kendra, Wyra, Khammam, Telangana State, India \\ *Corresponding author
}

\begin{tabular}{l} 
K e y w o r d s \\
$\begin{array}{l}\text { Chilli, Production, } \\
\text { Cost of cultivation }\end{array}$ \\
Article Info \\
$\begin{array}{l}\text { Accepted: } \\
\text { 07 January } 2021 \\
\text { Available Online: } \\
\text { 10 February } 2021\end{array}$ \\
\hline
\end{tabular}

\section{A B S T RA C T}

Chilli is intensively grown in Kharnrnam district of Telangana. Nevertheless, little research has been concentrated on the economic aspects of chilli cultivation in the recent past. Hence, the present study was undertaken with the following objectives: 1 . To study the investment pattern on chilli farms of different size groups 2 . To find out the costs and returns in chilli cultivation according to farm size. The data was collected pertaining to the agricultural year 2018-19. Data was collected from 120 respondents. The economic analysis of data indicating cost ' $C$ ' was found to be Rs. 393952.74, Rs. 416867.20 and Rs 420907.37 per hectare for marginal, small and big farmers respectively. The human labour utilization was inversely related with the farm size. Harvesting accounted for maximum share of total labour utilization. An inverse relationship was observed between the farm size and cattle labour utilization. Family labour utilization was also inversely related with the farm size. The total cost of cultivation was positively correlated with the farm size. Variable costs contributed nearly to the extent of 61.00 per cent of total cost of cultivation and exhibited direct relationship with farm size. There was a direct relationship between the farm size and productivity of chillies. Both the gross and net returns were positively correlated with farm size. All the income measures also showed direct relationship with farm size. The input-output ratio was quite high in chilli farms, revealing the profitability in farming. Economic analysis of data indicated that the total cost of chilli cultivation per ha was Rs 393952.74, 416867.20 and 420907.37 for marginal, small and big farmers respectively. Labour cost, seed, plant protection chemicals, manures and fertilizer constituted the major portion of the total cost of cultivation. Net returns over cost ' $\mathrm{C}$ ' was Rs. 118641.01, Rs. 137170.30 and Rs. 168030.13 per hectare and input-Output ratio at cost ' $\mathrm{C}$ ' was $1.30,1.33$ and 1.40 for marginal, small and big farmers respectively.

\section{Introduction}

Chilli (Capsicum annum L.) occupies an important place in Indian diet. It is an indispensable item in the kitchen as it is consumed daily as a condiment in one form or the other. Chilli is used as an essential condiment in foods for its pungency and red colour. Chilli is today one of India's major export attraction. It is the major spice contributing 40-42 per cent by volume, 22 per cent by value of total spices exported from India (Jagtap et al., 2014). Indian chilli is considered to be world famous for two 
important commercial qualities color and pungency levels. Indian chilli is mainly exported to Asian countries like Vietnam, Thailand, Sri Lanka, Bangladesh, U.A.E., Middle East and the Far East. During 201718, 4.44 lakh tonnes of chilli was exported to different countries (Source: Annual report 2017-18, Spices board of India, 2018) generating an income of 425632.74 lakhs (Source: Annual report 2017-18, Spices board of India, 2018). Chilli is an annual plant, comes in a wide variety of shapes, sizes, colour and in different degrees of pungency. It is thus variously called Capsicum, Paprika, Pimento, Sweet pepper, Red pepper, Cayenne pepper and Bird's eye chilli depending on the type of chilli and the manner in which it is prepared and used. Many varieties of chilli are grown for vegetables, spices, condiments, sauce and pickles. Products are available as powder and oleoresins. Chilli is considered as one of the commercial spice crops. It is the most widely used universal spice, named as wonder spice. There are over 50 spices produced in India and good numbers of them are grown in the countries which are indigenous. Among the spices consumed per head, dried chilli fruits constitute a major share (Rajur et al., 2008). In daily life, chillies are integral and the most important ingredient in many different cuisines around the world as it adds pungency, taste, flavour and colour to the dishes. Some varieties are famous for the red colour because of the Capsanthin pigment and others are known for biting pungency attributed to capsaicin. India also offers high capsaicin content chilli with or without stalks and with clipped stalks, and fresh and dried capsicum. Besides these properties chilli is a rich source of Vitamins $\mathrm{A}, \mathrm{C}, \mathrm{E}$ and $\mathrm{P}$ and has certain medicinal properties. Every 100 gms of dried pods yield about 160 calories of energy through $36 \mathrm{gms}$ carbohydrate, $18 \mathrm{gms}$ proteins, $16 \mathrm{gms}$ fat, $480 \mathrm{mg}$ calcium, $3.1 \mathrm{mg}$ phosphorous, $31 \mathrm{mg}$ iron, $2.5 \mathrm{mg}$ niacin, 640
I.U. vitamin 'A' and 40mg vitamin 'C' (Narayanan et al., 1999). The most important chilli growing states in India are Andhra Pradesh (25\%), Telangana (15\%), Maharashtra (13\%), Karnataka (12\%), Madhyapradesh (10\%), and Tamil Nadu (3\%) (Source: Horticulture Statistics Division, Department of Agriculture, Cooperation \& Farmers Welfare.- Horticultural Statistics at a Glance 2017) which together constitute nearly 75 per cent of the total area. The present study was undertaken to analyze cost and returns of chilli production in the state of Telangana. The major chilli growing areas in Telangana are Khammam, Mahabubabad, Gadwal and Warangal districts. In Khammam chilli is the predominant crop grown in almost all the mandals in an area of 19828 hectares (Season and Crop coverage Report, Department of Agriculture, 2018). It is one of the important chilli growing areas of the country. Some of the important varieties dominant in the market are Byadagi, Teja, Wonderhot, Jwala, Sannam, No.273 and LCA-334.

\section{Materials and Methods}

The present study was undertaken during 2018-19 in Khammam district of Telangana. This study is based on primary data collected from Chilli growers. Multistage random sampling technique was adopted in designing sampling frame for the study. In the first stage, Telangana state is selected purposively. In the second stage, Khammam district was selected based on the highest area under chilli in Telangana state. Similarly, in third stage six villages were selected randomly based on potentiality and highest area under chilli. The list of vegetable growers so obtained has been further regrouped under the category marginal, small and big farmers group on the basis of size of land holding making a total of 120 farmers in view of spread of chilli growers in different villages. The data was 
collected through pre-tested schedules by personal interviews. The primary data from sample farmers were collected by personal interview method by using pre-tested structured questionnaire. Cost concepts defined by Commission of Agricultural Cost and Prices (CACP) were followed. The data thus collected were presented in tabular form. The data were summarized with the help of statistical tools like averages, percentages etc. to obtain meaningful results.

\section{Cost concepts}

Cost $\mathrm{A}=$ All actual expenses in cash and kind incurred in production by the producer. The items covered in cost $\mathrm{A}$ are costs on:

i. Value of hired human labour,

ii. Value of hired and owned bullock labour,

iii. Value of hired and owned machinery labour,

iv. Value of owned and purchased seed,

v. Value of fertilizers, manures and chemical, vi. Value of insecticide and pesticides,

vii. Expenditure on irrigation,

viii. Land revenue and taxes,

ix. Interest paid on crop loan if taken,

$\mathrm{x}$. Depreciation on farm assets excluding land,

xi. Interest on working capital,

xii. Miscellaneous expenses.

Cost $\mathrm{A} 2=$ Cost $\mathrm{A}+$ Rent paid for leased-in land

Cost $\mathrm{B}=$ Cost $\mathrm{A}+$ Interest on value of owned capital assets (excluding land)

Cost $\mathrm{B} 2=$ Cost $\mathrm{B}+$ Rental value of owned land (net of land revenue) and rent paid for leased-in land

Cost $\mathrm{C}=$ Cost $\mathrm{B}+$ Imputed value of family labour

Cost $\mathrm{C} 2=$ Cost B2 + Imputed value of family labour
Cost $\mathrm{C} 3=$ Cost $\mathrm{C} 2+10$ per cent Cost $\mathrm{C} 2$ (on account of managerial functions performed by farmers)

For the estimation of profitability, the following income measures were used.

a) Net farm income (NFI) $=$ Gross income Cost C3 (total cost)

b) Family labour income (FLI) = Gross income - Cost B2

c) Farm business income $(\mathrm{FBI})=$ Gross income-Cost A

d) $\mathrm{B}$ : $\mathrm{C}$ ratio (Benefit cost ratio) $=$ Gross income/ Gross expenses

\section{Results and Discussion}

The results obtained from the present investigation as well as relevant discussions have been summarized below

\section{Input utilization in chilli production}

The results in Table 1 indicated that per hectare hired human labour was observed highest in big farmer's category i.e. 422.87 man days and at overall level it was 399.76 man days. The human labour utilization was inversely related with the farm size. The usage of bullock pair decreased from marginal farmers to big farmers, it was highest among marginal farmers (18.40 labour days) and lowest among big farmers (15.30 labour days) and average was 17.30 labour days where as the usage of machinery (tractor etc) was highest among big farmers (20.88 hours) and least among small farmers (12.42 hours). The use of manures was highest among big farmers (23.93 cart loads) compared to marginal farmers group (18.48) thus directly reflecting on use of fertilizers which was low among big farmers (1366.30 
kgs) compared to marginal farmers (1378.02 $\mathrm{kgs})$. Even use of plant protection chemicals was high among marginal farmers (10.51 lit) due to lack of knowledge on proper use of chemicals and the use is low among big farmers (9.04 lit) and overall usage is 9.71 lit.

\section{Cost of cultivation in chilli per hectare}

The per hectare cost of cultivation in chilli by selected chilli growers is presented in Table 2 and it is observed from the table that per hectare total cost of cultivation of overall farmers for the selected sample is Rs. 410575.77 amongst the different items of expenditure, out of which 41.44 per cent share in total cost is accounted for human labour and it is highest of all the costs incurred in the chilli cultivation. Analogously among the fixed costs, rental value of the owned land accounted for 17.41 per cent of the total cost of cultivation. It is also noted from Table 2 that per hectare average cost $\mathrm{A}$ of chilli cultivation was Rs. 269676.62 (65.68 \%) among overall farmers and it was Rs 257833.85 (65.45 \%), Rs. 272898.22 (65.46 $\%)$ and Rs 278297.78 (66.12 \%) among marginal, small and big farmers respectively accounting for more than 65.00 percent of total operational costs incurred per hectare in cultivation of chilli which includes land revenue, depreciation and interest on working capital. It was seen higher among big farmers. Cost B was Rs. 328755.74 (83.45 \%), Rs. $352895.20(84.65 \%)$ and Rs. 362517.37 $(86.13 \%)$ for marginal, small and big farmers respectively.

Table.1 Input utilization in chilli production (per hectare) N=120

\begin{tabular}{|c|c|c|c|c|c|c|}
\hline \multirow[t]{2}{*}{ S.No } & \multirow[t]{2}{*}{ Particulars } & \multirow[t]{2}{*}{ Unit } & \multicolumn{4}{|c|}{ Size of the Land Holding } \\
\hline & & & $\begin{array}{c}\text { Marginal } \\
\text { farmers (upto } \\
\text { 1ha) }\end{array}$ & $\begin{array}{c}\text { Small } \\
\text { farmers } \\
\text { (1-2 ha) }\end{array}$ & $\begin{array}{l}\text { Big farmers } \\
\text { (above } 2 \text { ha) }\end{array}$ & $\begin{array}{l}\text { Overall } \\
\text { farmers }\end{array}$ \\
\hline 1 & \multicolumn{2}{|c|}{ Hired human labour } & & & & \\
\hline $\mathbf{a}$ & Male & Days & 143.31 & 153.71 & 157.42 & 151.48 \\
\hline \multirow[t]{2}{*}{ b } & Female & Days & 221.80 & 257.60 & 265.45 & 248.28 \\
\hline & Total & & 365.11 & 411.31 & 422.87 & 399.76 \\
\hline 2 & Bullock pair & Pair & 18.40 & 18.20 & 15.30 & 17.30 \\
\hline 3 & Machine charges & Hrs & 12.42 & 16.55 & 20.88 & 16.62 \\
\hline 4 & Manures & Cart load & 18.48 & 22.47 & 23.93 & 21.63 \\
\hline 5 & Irrigation & days & 57.97 & 56.90 & 62.38 & 59.08 \\
\hline \multirow[t]{5}{*}{6} & Fertilizers & $\mathrm{Kg}$ & & & & \\
\hline & Nitrogen & $\mathrm{Kg}$ & 806.80 & 804.20 & 801.90 & 804.30 \\
\hline & Phosphorus & $\mathrm{Kg}$ & 282.02 & 278.61 & 277.44 & 279.36 \\
\hline & Potassium & $\mathrm{Kg}$ & 289.20 & 287.22 & 286.96 & 287.79 \\
\hline & Total & & 1378.02 & 1370.03 & 1366.30 & 1371.45 \\
\hline 7 & Seed & $\mathrm{Kg}$ & 0.86 & 0.85 & 0.84 & 0.85 \\
\hline 8 & $\begin{array}{l}\text { Plant protection } \\
\text { chemicals }\end{array}$ & Litres & 10.51 & 9.59 & 9.04 & 9.71 \\
\hline \multirow[t]{4}{*}{9} & \multicolumn{2}{|c|}{ Family Human Labour } & & & & \\
\hline & Male & Days & 106.24 & 105.24 & 92.85 & 101.44 \\
\hline & Female & Days & 133.30 & 129.60 & 122.14 & 128.35 \\
\hline & Total & & 239.54 & 234.84 & 214.99 & 229.79 \\
\hline
\end{tabular}


Table.2 Cost of chilli cultivation by the sample farmers of different size groups in the study area (Rs. per hectare) $n=120$

\begin{tabular}{|c|c|c|c|c|c|}
\hline \multirow[t]{2}{*}{ S.No } & \multirow[t]{2}{*}{ Particulars } & \multicolumn{4}{|c|}{ Size of the Land Holding } \\
\hline & & $\begin{array}{c}\text { Marginal } \\
\text { farmers (upto } \\
\text { 1ha) }\end{array}$ & $\begin{array}{l}\text { Small } \\
\text { farmers } \\
(1-2 \text { ha) }\end{array}$ & $\begin{array}{l}\text { Big farmers } \\
\text { (above } 2 \text { ha) }\end{array}$ & $\begin{array}{l}\text { Overall } \\
\text { farmers }\end{array}$ \\
\hline \multicolumn{6}{|c|}{1} \\
\hline $\mathbf{a}$ & Male & $\begin{array}{c}42993.00 \\
(10.92)\end{array}$ & $\begin{array}{c}46113.00 \\
(11.07)\end{array}$ & $\begin{array}{c}47226.00 \\
(11.23)\end{array}$ & $\begin{array}{c}45444.00 \\
(11.09)\end{array}$ \\
\hline b & Female & $\begin{array}{c}55450.00 \\
(14.07)\end{array}$ & $\begin{array}{c}64400.00 \\
(15.44)\end{array}$ & $\begin{array}{c}66362.50 \\
(15.77)\end{array}$ & $\begin{array}{c}62070.83 \\
(15.12)\end{array}$ \\
\hline 2 & Bullock pair & $\begin{array}{c}11040.00 \\
(2.81)\end{array}$ & $\begin{array}{c}10920.00 \\
(2.62)\end{array}$ & $\begin{array}{c}9180.00 \\
(2.18)\end{array}$ & $\begin{array}{c}10380.00 \\
(2.52)\end{array}$ \\
\hline 3 & Machine charges & $4968.00(1.27)$ & $\begin{array}{c}6620.00 \\
(1.59)\end{array}$ & $\begin{array}{c}8352.00 \\
(1.98)\end{array}$ & $\begin{array}{c}6646.67 \\
(1.62)\end{array}$ \\
\hline 4 & Manures & $\begin{array}{c}20328.00 \\
(5.17)\end{array}$ & $\begin{array}{c}24717.00 \\
(5.93)\end{array}$ & $\begin{array}{c}26323.00 \\
(6.27)\end{array}$ & $\begin{array}{c}23789.33 \\
(5.79)\end{array}$ \\
\hline 5 & Irrigation & $\begin{array}{c}26086.50 \\
(6.62)\end{array}$ & $\begin{array}{c}25604.55 \\
(6.14)\end{array}$ & $\begin{array}{c}28071.00 \\
(6.67)\end{array}$ & $\begin{array}{c}26587.35 \\
(6.47)\end{array}$ \\
\hline \multirow[t]{5}{*}{6} & Fertilizers & & & & \\
\hline & Nitrogen & $4840.80(1.22)$ & $\begin{array}{c}4825.20 \\
(1.16)\end{array}$ & $\begin{array}{c}4811.40 \\
(1.14)\end{array}$ & $\begin{array}{c}4825.80 \\
(1.17)\end{array}$ \\
\hline & Phosphorus & $6768.48(1.71)$ & $\begin{array}{c}6686.64 \\
(1.60)\end{array}$ & $\begin{array}{c}6658.56 \\
(1.58)\end{array}$ & $\begin{array}{c}6704.56 \\
(1.64)\end{array}$ \\
\hline & Potassium & $5205.60(1.32)$ & $\begin{array}{c}5169.96 \\
(1.24)\end{array}$ & $\begin{array}{c}5165.28 \\
(1.23)\end{array}$ & $\begin{array}{c}5180.28 \\
(1.26)\end{array}$ \\
\hline & Total & $\begin{array}{c}16814.88 \\
(4.25)\end{array}$ & $\begin{array}{c}16681.80 \\
(4.00)\end{array}$ & $\begin{array}{c}16635.24 \\
(3.95)\end{array}$ & $\begin{array}{c}16710.64 \\
(4.07)\end{array}$ \\
\hline 7 & Seed & $\begin{array}{c}21070.00 \\
(5.34)\end{array}$ & $\begin{array}{c}20825.00 \\
(5.00)\end{array}$ & $\begin{array}{c}20580.00 \\
(4.89)\end{array}$ & $\begin{array}{c}20825.00 \\
(5.07)\end{array}$ \\
\hline 8 & Plant protection chemicals & $\begin{array}{c}36785.00 \\
(9.33)\end{array}$ & $\begin{array}{c}33565.00 \\
(8.05)\end{array}$ & $\begin{array}{c}31640.00 \\
(7.51)\end{array}$ & $\begin{array}{c}33996.67 \\
(8.28)\end{array}$ \\
\hline 9 & Incidental Charges & $518.02 \quad(0.13)$ & $\begin{array}{c}546.26 \\
(0.13)\end{array}$ & $\begin{array}{c}547.38 \\
(0.12)\end{array}$ & $\begin{array}{l}537.22 \\
(0.13)\end{array}$ \\
\hline 10 & Repairing charges & $444.02(0.11)$ & $\begin{array}{l}507.25 \\
(0.12)\end{array}$ & $\begin{array}{l}547.38 \\
(0.13)\end{array}$ & $\begin{array}{l}499.55 \\
(0.12)\end{array}$ \\
\hline 11 & Miscellaneous Charges & $4403.25(1.12)$ & $\begin{array}{c}4448.18 \\
(1.06)\end{array}$ & $\begin{array}{c}4535.46 \\
(1.07)\end{array}$ & $\begin{array}{c}4462.30 \\
(1.08)\end{array}$ \\
\hline \multirow[t]{3}{*}{14} & Working Capital & $\begin{array}{c}240900.67 \\
(61.14)\end{array}$ & $\begin{array}{c}254948.04 \\
(61.15)\end{array}$ & $\begin{array}{c}259999.96 \\
(61.77)\end{array}$ & $\begin{array}{c}251949.56 \\
(61.36)\end{array}$ \\
\hline & Land Revenue & $472.74 \quad(0.12)$ & $\begin{array}{l}416.86 \\
(0.10)\end{array}$ & $\begin{array}{c}420.90 \\
(0.10)\end{array}$ & $\begin{array}{l}410.57 \\
(0.10)\end{array}$ \\
\hline & Depreciation of Assets & $2109.12(0.53)$ & $\begin{array}{c}2263.11 \\
(0.54)\end{array}$ & $\begin{array}{c}2306.83 \\
(0.55)\end{array}$ & $\begin{array}{c}2226.35 \\
(0.54)\end{array}$ \\
\hline
\end{tabular}




\begin{tabular}{|c|c|c|c|c|c|}
\hline 15 & $\begin{array}{l}\text { Interest on Working } \\
\text { capital }(6 \%)\end{array}$ & $\begin{array}{c}14454.04 \\
(3.66)\end{array}$ & $\begin{array}{c}15296.88 \\
(3.67)\end{array}$ & $\begin{array}{c}15600.00 \\
(3.70)\end{array}$ & $\begin{array}{c}15116.97 \\
(3.68)\end{array}$ \\
\hline 16 & Cost-A & $\begin{array}{c}257833.85 \\
(65.45)\end{array}$ & $\begin{array}{c}272898.22 \\
(65.46)\end{array}$ & $\begin{array}{l}278297.78 \\
(66.12)\end{array}$ & $\begin{array}{c}269676.62 \\
(65.68)\end{array}$ \\
\hline 17 & Rental Value of land & $\begin{array}{c}64568.63 \\
(16.39)\end{array}$ & $\begin{array}{c}72965.73 \\
(17.50)\end{array}$ & $\begin{array}{c}76907.34 \\
(18.27)\end{array}$ & $\begin{array}{c}71480.57 \\
(17.41)\end{array}$ \\
\hline 18 & $\begin{array}{l}\text { Interest on fixed capital } \\
\text { (6\% of rental value+ } \\
\text { Depreciation+ Land } \\
\text { revenue) }\end{array}$ & $6353.26(1.61)$ & $\begin{array}{c}7031.24 \\
(1.69)\end{array}$ & $\begin{array}{c}7312.26 \\
(1.74)\end{array}$ & $\begin{array}{c}6898.92 \\
(1.68)\end{array}$ \\
\hline 19 & Cost - B & $\begin{array}{c}\text { 328755.74 } \\
(\mathbf{8 3 . 4 5 )}\end{array}$ & $\begin{array}{c}\text { 352895.20 } \\
(84.65)\end{array}$ & $\begin{array}{c}\mathbf{3 6 2 5 1 7 . 3 7} \\
(\mathbf{8 6 . 1 3})\end{array}$ & $\begin{array}{c}\mathbf{3 4 8 0 5 6 . 1 1} \\
(84.77)\end{array}$ \\
\hline 20 & Family human labour & & & & \\
\hline a) & Male & $\begin{array}{l}31872.00 \\
(8.10)\end{array}$ & $\begin{array}{l}31572.00 \\
(7.57)\end{array}$ & $\begin{array}{l}27855.00 \\
(6.62)\end{array}$ & $\begin{array}{l}30433.00 \\
(7.42)\end{array}$ \\
\hline b) & Female & $\begin{array}{l}33325.00 \\
(8.45)\end{array}$ & $\begin{array}{l}32400.00 \\
(7.78)\end{array}$ & $\begin{array}{l}30535.00 \\
(7.25)\end{array}$ & $\begin{array}{l}32086.67 \\
(7.81)\end{array}$ \\
\hline 21 & Cost $-C$ & $\begin{array}{l}\text { 393952.74 } \\
(\mathbf{1 0 0 . 0 0 )}\end{array}$ & $\begin{aligned} & 416867.2 \\
0 & (100.00)\end{aligned}$ & $\begin{array}{l}420907.37 \\
(100.00)\end{array}$ & $\begin{array}{r}410575.7 \\
7(100.00)\end{array}$ \\
\hline
\end{tabular}

Table.3 Economics of Chilli Cultivation in different size groups (per hectare) N=120

\begin{tabular}{|l|l|c|c|c|c|}
\hline S.No & Particulars & \multicolumn{3}{|c|}{ Size of the Land Holding } \\
\cline { 3 - 6 } & & $\begin{array}{c}\text { Marginal } \\
\text { farmers } \\
\text { (upto 1ha) }\end{array}$ & $\begin{array}{c}\text { Small } \\
\text { farmers (1-2 } \\
\text { ha) }\end{array}$ & $\begin{array}{c}\text { Big farmers } \\
\text { (above 2 ha) }\end{array}$ & $\begin{array}{c}\text { Overall } \\
\text { farmers }\end{array}$ \\
\hline $\mathbf{1}$ & Average Yield (Q//ha) & 58.75 & 63.50 & 67.50 & 63.25 \\
\hline $\mathbf{2}$ & $\begin{array}{l}\text { Average price received } \\
\text { per quintal }\end{array}$ & 8725.00 & 8725.00 & 8725.00 & 8725.00 \\
\hline $\mathbf{3}$ & Gross Returns (Rs.) & 512593.75 & 554037.50 & 588937.50 & 551856.25 \\
\hline $\mathbf{4}$ & Cost of Production (Rs.) & 320293.37 & 343600.84 & 352898.29 & 338930.83 \\
\hline $\mathbf{5}$ & Cost of Cultivation (Rs.) & & & & \\
\hline & At Cost 'A' & 257833.85 & 272898.22 & 278297.78 & 269676.62 \\
\hline & At Cost 'B' & 328755.74 & 352895.20 & 362517.37 & 348056.11 \\
\hline & At Cost 'C' & 393952.74 & 416867.20 & 420907.37 & 410575.77 \\
\hline $\mathbf{6}$ & Net return over cost (Rs.) & & & & \\
\hline & At Cost 'A' & 254759.90 & 281139.28 & 310639.72 & 282179.63 \\
\hline & At Cost 'B' & 183838.01 & 201142.30 & 226420.13 & 203800.14 \\
\hline & At Cost 'C' & 118641.01 & 137170.30 & 168030.13 & 141280.48 \\
\hline \multirow{7}{*}{} & Input-Output Ratio & & & & \\
\hline & At Cost 'A' & 1.99 & 2.03 & 2.12 & 2.05 \\
\hline & At Cost 'B' & 1.56 & 1.57 & 1.62 & 1.59 \\
\hline & At Cost 'C' & 1.30 & 1.33 & 1.40 & 1.34 \\
\hline
\end{tabular}


Fig.1 Cost of cultivation in chilli

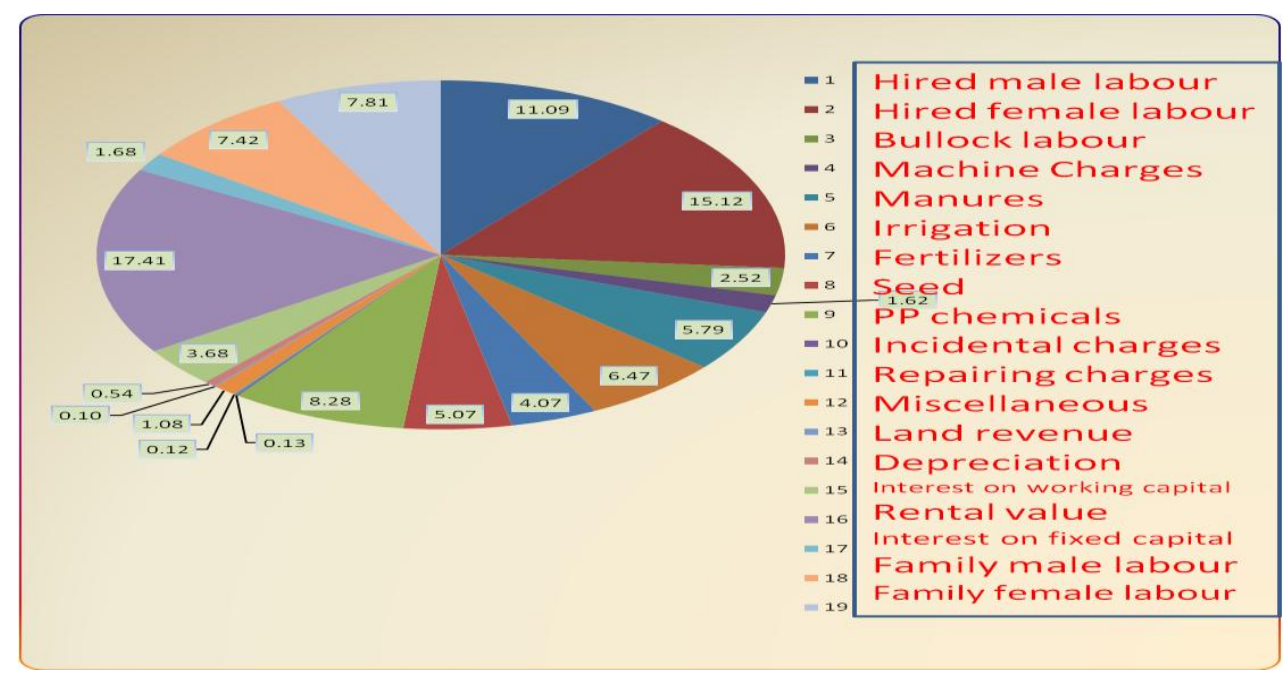

Cost C detail of chilli cultivation estimated per ha was Rs. 393952.74, Rs. 416867.20 and Rs. 420907.37 for marginal, small and big farmers respectively. It is observed from table 2 that on an average per ha rental Value of land was 17.41 per cent followed by hired female labour $(15.12 \%)$, hired male labour $(11.09 \%)$, plant protection chemicals $(8.28$ $\%)$, family female labour (7.81 \%), family male labour $(7.42 \%)$, irrigation $(6.47 \%)$, manures $(5.79 \%)$ and seed $(5.07 \%)$ are the major items of costs incurred in cultivation of chilli.

\section{Economics of chilli production}

It could be inferred from Table 3 that the gross returns per ha from chilli production at overall level was Rs. 551856.25. The gross returns earned per ha ranged between Rs. 512593.75, Rs. 554037.50 and Rs 588937.50 for marginal, small and big farmers respectively. Cost of production at overall level was Rs. 338930.83 and Rs. 320293.37, Rs. 343600.84 , Rs. 352898.29 for marginal, small and big farmers respectively. Cost of cultivation at overall level cost 'A', cost 'B' and cost ' $C$ ' were Rs. 269676.62, Rs. 348056.11 and Rs. 410575.77 respectively. Net returns per hectare of Cost ' $A$ ' is highest i.e. Rs. 310639.72 in big size group followed by Rs. 281139.28 in small size group and Rs. 254759.90 in marginal size group. The net return at Cost ' $\mathrm{C}$ ' in marginal, small and big farmer's size group were Rs. 118641.01, Rs. 137170.30, and Rs. 168030.13 respectively. In chilli the input-output ratio for overall size group at Cost 'A', Cost ' $\mathrm{B}$ ' and Cost 'C' were $2.05,1.59$ and 1.34 respectively. The inputoutput ratio calculated at Cost ' $\mathrm{A}$ ' and Cost ' $C$ ' were greater than unity in all the size groups indicating there by the production of chilli was profitable. Input-output ratio at Cost 'A' was highest i.e. 2.12 in big size group followed by small (2.03) and marginal (1.99) size groups. It is also inferred from the study that around 90 per cent of chilli is traded in the market by way of retailers and wholesalers and only 10 per cent within the village and is in conformity with Samshimastung and Giribabu 2016. The present findings are also supported by Ruchira (2010) who also reported higher return from chilli cultivation.

The study revealed that per hectare cost of cultivation of chilli at cost ' $\mathrm{C}$ ' was highest in the big farmer group i.e. Rs. 420907.37 followed by small farmers group Rs. 416867.20 and marginal farmers group Rs. 
393952.74. The average yield and gross returns per hectare increased with the increase in size of farms. The net returns at Cost ' $B$ ' for marginal, small and big farmers were Rs. 183838.01, Rs. 201142.30, and Rs. 226420.13 respectively while net returns at Cost ' $C$ ' for marginal, small and big farmers were Rs. 118641.01, Rs. 137170.30, and Rs. 168030.13 respectively. The results were in line with the results of Jorwar et al., (2018).

In conclusion the prices of inputs required for chilli cultivation has increased many fold over a decade and hence the cost of production in general has increased. On the contrary the price of output not only fluctuated over years, but also did not rise in tune with increase in the input price. The national policy is to encourage condiments production; the purpose cannot be achieved without fair and remunerative price and adequate incentive to the chilli growers in the area. The price has to be remunerative enough to earn a legitimate profit. Alternatively, the marginal farmers could also be encouraged to augment to get maximum profit, by supporting reduction in their cost of cultivation by subsidizing the inputs like quality seed and plant protection materials etc. The proper use of improved technology and improved practices of chilli production need to be demonstrated. Awareness should be created among the farmers through trainings, exposure visits, field visits, field days and demonstrations etc on use of latest technologies in agriculture by the extension agents of agriculture and allied departments. Hence, the extension worker and planner should be taken care on this point. It was revealed from the study that chilli production required much higher initial investment. Hence, to reduce the risk aversion influence on productivity, an attractive crop insurance scheme needs to be implemented effectively in the area. The present study shows similarities with the work of Hiremath (1994) who reported material cost like fertilizers, plant protection measures and labour charges as the major components of raising crops like chilli. The future lies in selling of the farm produce at Inter-state trade platforms in wholesale markets through eNAM (Electronic National Agriculture market) thereby preventing involvement of the middlemen. It should be encouraged by networking all the markets in the state as it helps the farmers in getting better market access and earn higher income.

\section{References}

Annual report 2017-18, Spices board of India, 2018. Department of Agriculture, Cooperation \& Farmers Welfare, Ministry of Agriculture \& Farmers Welfare, Government of India.

Hiremath, A.P. (1994).Production and marketing of dry chillies in KarnatakaAn economic analysis. M.Sc (Ag.) Thesis, University of Agricultural Sciences, Dharwad (India).

Horticultural Statistics at a Glance 2017, Horticulture Statistics Division, Department of Agriculture, Cooperation \& Farmers Welfare, Ministry of Agriculture \& Farmers Welfare Government of India, PDES - 256 (E), $500-2017$ - (DSK-III).

Jadav KS, Patel JK, Parmar HC. 2014. Comparative economics of green chilli cultivation under drip and conventional irrigation methods a case study of middle Gujarat. Int. J Agric. Sc. \&Vet. Med. 2014; 2(2): 71-78.

Jain BC, Ajay Tegar. 2013. Economics of production and marketing of chilli in Jaspur district of Chattisgarh. Agril. Mktg. 2003; 46(3):5-10.

Jagtap, P.P., Shingane, U.S., Kulkarni, K.P. 2014. Resource use efficiency and economics of marketing of green chilli. Journal of Spices and Aromatic crops 23(1): 32-37. 
Jagtap, P.P., Shingane, U.S., Kulkarni, K.P. 2012. Economics of Chilli Production in India. African Journal of Basic \& Applied Sciences 4 (5): 161-164.

Jorwar RM, SM Sarap and VU Chavan 2018. Economics of production and marketing of chilli in Amravati district. Journal of Pharmacognosy and Phytochemistry 2018; 7(2): 310-316

Mishra, J.P., Vishwakarma, R.S. and Rawat, S.K. 1999. Production and marketing of chillies. Bihar J. Agric. Mktg., 7: 336343.

Narayanan, S.S., S. Hedge, A.R. Sadananda and S. Chelliah, 1999. Commerce and utility considerations of chillies. Kisan World. 26(9): 73-75.

Rajur, B.C., Patil, B., Basavraj, H. 2008. Economics of chilli production in Karnataka. Karnataka Journal of Agricultural Sciences 21(2): 237-240.

Ruchira Shukla. 2010. Economics of chilli cultivation in Jaipur district of Rajasthan. 2010. International Journal of Commerce and Business Management (October, 2010) Vol. 3. Issue 2 Pg no: 267-269
Samshimastung, Giribabu, M. 2016. An economic analysis of production and marketing of chilli in Mokokchung district of Nagaland. Arthashastra: Indian Journal of Economics and Research 5(1): 31-49.

Shende NV, Meshram RR. Cost benefit analysis and marketing of chilli. 2015. American International J. of Res. in Formal, Applied \& Natural Sciences. 2015; 11(1):46-54.

Singh RP, Anupama Toppo. 2010. Economics of production and marketing of chilli in Kanke block of Ranchi district. Ind. J Agril. Mktg. 2010; 24(2):3-16.

Srikala M, Bhavani Devi I, Subramanyam V and Ananda T. 2016. Cost of cultivation and price spread of chillies in guntur district of Andhra Pradesh. International Journal of Agriculture, Environment and Biotechnology. 2016; 9(2): 299-303 April 2016

Season and Crop coverage Report, Kharif 2018, Department of Agriculture, Government of Telangana, India.

\section{How to cite this article:}

Raja Madhu Shaker, B., J. Hemantha Kumar, V. Chaitanya, P. Sriranjitha, K. Ravi Kumar and Jagan Mohan Rao, P. 2021. Economics of Chilli Cultivation in Khammam District of Telangana. Int.J.Curr.Microbiol.App.Sci. 10(02): 893-901. doi: https://doi.org/10.20546/ijcmas.2021.1002.105 